\title{
Antimicrobial Resistance in Humans, Animals, Water and Household Environs in Rural Andean Peru: Exploring Dissemination Pathways through the One Health Lens
}

\author{
Stella M. Hartinger ${ }^{1,2,3, *} \mathbb{0}$, Maria Luisa Medina-Pizzali ${ }^{1} \mathbb{C}$, Gabriela Salmon-Mulanovich ${ }^{1,4} \mathbb{D}^{\mathbb{O}}$, \\ Anika J. Larson ${ }^{1,5}$, Maria Pinedo-Bardales ${ }^{6}$, Hector Verastegui ${ }^{1,2,3}$, Maribel Riveros ${ }^{7}$ and Daniel Mäusezahl ${ }^{2,3}$ \\ check for \\ updates \\ Citation: Hartinger, S.M.; \\ Medina-Pizzali, M.L.; \\ Salmon-Mulanovich, G.; Larson, A.J.; \\ 1 School of Public Health and Administration, Universidad Peruana Cayetano Heredia, Lima 15102, Peru; \\ maria.medina.p@upch.pe (M.L.M.-P.); hector.verastegui@swisstph.ch (H.V.) \\ 2 Department of Epidemiology and Public Health, Swiss Tropical and Public Health Institute, \\ 4002 Basel, Switzerland; daniel.maeusezahl@unibas.ch \\ 3 Swiss Tropical and Public Health Institute, University of Basel, 4001 Basel, Switzerland \\ 4 Institute for Nature, Earth and Energy, Pontificia Universidad Católica del Perú, Lima 15102, Peru; \\ gsalmonm@pucp.edu.pe \\ 5 School of Medicine, University of Washington, Seattle, WA 98195, USA; larsona@uw.edu \\ 6 Instituto de Medicina Tropical Alexander von Humboldt, Universidad Peruana Cayetano Heredia, \\ Lima 15102, Peru; maria.pinedo@upch.pe \\ 7 School of Medicine, Universidad Peruana Cayetano Heredia, Lima 15102, Peru; maribel.riveros@upch.pe \\ * Correspondence: stella.hartinger.p@upch.pe
} Pinedo-Bardales, M.; Verastegui, H.; Riberos, M.; Mäusezahl, D. Antimicrobial Resistance in Humans, Animals, Water and Household Environs in Rural Andean Peru: Exploring Dissemination Pathways through the One Health Lens. Int. J Environ. Res. Public Health 2021, 18, 4604. https://doi.org/10.3390/ ijerph18094604

Academic Editors:

Aneta Nowakiewicz and Sebastian Gnat

Received: 4 February 2021

Accepted: 12 April 2021

Published: 27 April 2021

Publisher's Note: MDPI stays neutral with regard to jurisdictional claims in published maps and institutional affiliations.

Copyright: (c) 2021 by the authors. Licensee MDPI, Basel, Switzerland This article is an open access article distributed under the terms and conditions of the Creative Commons Attribution (CC BY) license (https:// creativecommons.org/licenses/by/ $4.0 /)$
Abstract: Antimicrobial resistance (AMR) is a global public health threat, especially for low and middle-income countries (LMIC) where the threat has not been fully identified. Our study aims to describe E. coli AMR in rural communities to expand our knowledge on AMR bacterial contamination. Specifically, we aim to identify and describe potential dissemination routes of AMR-carrying bacteria in humans (children's stools), community water sources (reservoirs and household sources), household environments (yard soil) and domestic animals of subsistence farmers in rural Andean areas. Our cross-sectional study was conducted in rural households in the region of Cajamarca, Peru. A total of 266 samples were collected. Thirty-four point six percent of reservoir water and $45 \%$ of household water source samples were positive for thermotolerant coliforms. Of the reservoir water samples, $92.8 \%$ were positive for E. coli, and 30.8\% displayed resistance to at least one antibiotic, with the highest resistance to tetracycline. E. coli was found in $57.1 \%$ of the household water sources, $18.6 \%$ of these isolates were multidrug-resistant, and displayed the highest resistance to tetracycline (31.3\%). Among samples from the children's drinking water source, $32.5 \%$ were positive for thermotolerant coliforms, and $57.1 \%$ of them were E. coli. One third of E. coli isolates were multidrug-resistant and displayed the highest AMR to tetracycline (41.6\%) and ampicillin (25\%). Thermotolerant coliforms were found in all the soil samples, $43.3 \%$ of the isolates were positive for E. coli, $34.3 \%$ of the E. coli isolates displayed AMR to at least one antibiotic, and displayed the highest AMR to tetracycline $(25.7 \%)$. We determined thermotolerant coliforms in $97.5 \%$ of the child feces samples; $45.3 \%$ of them were E. coli, $15.9 \%$ displayed multidrug resistance, and displayed the highest resistance to ampicillin (34.1\%). We identified thermotolerant coliforms in $67.5 \%$ of the animal feces samples. Of those, $38.7 \%$ were E. coli, and $37.7 \%$ were resistant to at least one antibiotic. For all the samples, the prevalence of resistance to at least one antibiotic in the E. coli and Klebsiella spp. isolates was almost $43 \%$ and the prevalence of MDR in the same isolates was nearly $9 \%$, yet the latter nearly doubled $(15.9 \%)$ in children's stools. Our results provide preliminary evidence for critical pathways and the interconnectedness of animal, human and environmental transmission but molecular analysis is needed to track dissemination routes properly.

Keywords: antimicrobial resistance; E. coli; one health; environment; child feces; Peru 


\section{Introduction}

Antimicrobial resistance (AMR) has been labelled a public health threat, particularly for developing economies [1]. Treatment failures caused by AMR result in an increased risk of mortality and unnecessary burden to healthcare infrastructure, among others [2,3]. The AMR consequences for the health systems and patient health outcomes [4-6] are a policy challenge that directly influences community life. As the threat of AMR grows for many infectious diseases, filling the research gaps of AMR in Peru is essential.

Escherichia coli (E. coli)—and other commensal and enteric bacteria-may play a key role in the propagation of AMR genes. [7] Since fecal microbiota serves as the reservoir of these genes [8], which could be transferred to pathogenic organisms [9], the risk for resistant infections in the community increases. Multiple studies in Peru reported growing rates of AMR in commensal and enteric bacteria [10-12]. Many AMR genes significant in clinical settings are believed to have originated from non-pathogenic bacteria [13]. Resistance to ampicillin, cotrimoxazole, tetracycline, chloramphenicol, nalidixic acid and ciprofloxacin was reported in E. coli recovered among children in a periurban population in Peru [14]. Likewise, there is evidence of AMR in enterobacteria found in children across different environments: rural towns of the Amazon and Andean regions, periurban slums in desert coastal cities, and villages in the Amazon region [15-17]. Nevertheless, most of the evidence for AMR in human populations is focused on urban and periurban settings rather than rural areas [15]. On the other hand, extended-spectrum $\beta$-lactamases (ESBL) production is common in E. coli and other enterobacteria. ESBL-producing microorganisms cause high-mortality infections, given that ESBL hydrolyses the therapeutically important carbapenems and other beta-lactam antibiotics. As a result, therapeutic options available are greatly narrowed down [18].

The increase in AMR worldwide is a result of inappropriate antibiotics prescription by healthcare providers, treatment adherence among patients who do not use the antibiotics as prescribed, over-the-counter availability of antibiotics without a prescription [19], the inadequate use of antimicrobials in animal production, and the absence of integrated surveillance programs for antimicrobial resistance [20], which should focus on humans, animals and the environment [21]. In addition, unhygienic living conditions and the exposure to untreated or poorly treated water aggravate the AMR problem in developing countries [18], especially in rural settings [17].

The amount of antimicrobials used in animal production exert environmental pressure favoring the generation, and spread of AMR bacteria through different routes, mainly soil, water, food and farm animals $[19,22,23]$. Food-producing animals are commonly carriers of AMR and MDR bacteria, causing dissemination of AMR into humans-farm workers being at a higher risk-and ecosystems [7]. Sewage and surface water contaminated with sewage effluents are commonly used in the irrigation of crops, and animal drinking supply, driving the spread and maintenance of AMR bacteria in the environment [24]. Other factors prompting AMR include environmental contamination with industrial effluents containing metals and biocides, and the use of pesticides in agriculture, which can select for AMR genes in bacteria [25]. The lack of water treatment in the households, [17] consumption of conventional chicken - raised with antibiotics-[16] and the presence of antibiotics in dairy products [26] are factors favoring the dissemination of AMR in Peruvian ecosystems.

The One Health concept recognizes that "human health and animal health are interdependent and bound to the health of the ecosystems in which they exist" [27]. It has been specifically proposed as a framework to address AMR by the World Health Organization (WHO), the Food and Agriculture Organization, and the World Organization for Animal Health $[28,29]$. The WHO 2018 report on antimicrobial use and AMR, recommended their surveillance under a One Health approach [30]. While there are existing regulations on the use of antimicrobials for animal production in Peru, these are not closely enforced [26]. Regulations center on the types of antibiotics used and the detection of residue in products for human consumption and are also included in the National Plan to Confront Antimicrobial Resistance [31]. Furthermore, there are several additional barriers to implementing this 
concept, including parallel surveillance systems on human and animal health and ignoring the potential role of wildlife species $[32,33]$.

Adopting a One Health approach [34], this study aimed to describe AMR in San Marcos, Cajamarca, building on our current knowledge on AMR bacterial contamination [17]. We aimed to investigate the presence of AMR thermotolerant coliforms (i.e., E. coli, Klebsiella, Enterobacter, Citrobacter) in humans (stool samples from children), environments like community water sources (reservoirs and household sources), household environments (yard's soil), and domestic animals of subsistence farmers (e.g., pigs, poultry); and to propose carriage and dissemination routes of AMR bacteria in the household environment. Our study's findings could be useful for policy makers on this critical issue in the context of rural Peru and may also be applicable to other rural areas in the Andean region.

\section{Methods}

\subsection{Study Site}

Our study was conducted in rural homes of the San Marcos and Cajabamba provinces in the region of Cajamarca, Peru. This region is located approximately $2200-4000 \mathrm{~m}$ above sea level. Households typically obtain drinking water from central community reservoirs that are piped directly into individual homes or their courtyards. Among homes in this community, the preferred method of household water treatment is boiling [35], and most homes own livestock. Most small animals such as pigs and birds roam freely around household environs.

\subsection{Study Design}

Using a cross-sectional design, we purposely selected households with high AMR levels in the child's drinking water. These households came from among 102 communities in the northern highlands that had previously participated in a community-randomized controlled trial [36]. Homes that had a child under five years, a drinking water sample positive for E. coli with AMR, and homes keeping farm animals (mainly pigs and fowl) (unpublished data) were targeted and invited to participate in this study. All households were enrolled between May and June 2019.

\subsubsection{Sample Collection}

Trained fieldworkers visited each participating household $(\mathrm{N}=40)$ in the morning on two consecutive days to collect stool samples from children and animals, drinking water samples, and soil samples from the household's yard. We also collected water samples from a community water source. In addition, a household questionnaire was used to identify potential risk and protective factors to AMR, and corroborate AMR dissemination pathways in rural settings. A total of 266 samples were collected. For further pathogen identification, all samples were stored for up to three days in peptone media vials and were transported for analysis to the Enteric Diseases and Nutrition and Antibiotic Resistance Laboratory at the Tropical Medicine Institute, Universidad Peruana Cayetano Heredia, Lima.

\section{Human and Animal Fecal Samples}

Animal sample collection: We collected two rectal or cloacal swabs of fresh stool samples, ideally one from a domestic animal (dog, cat) and one from a farm animal (cow, pig, fowl). If the combination was not possible, collecting the same animal type was permitted. One veterinarian and one field worker were responsible for collecting the samples. The handling of the animal was done by the owner (to avoid additional stress on the animal) and a trained fieldworker while the veterinarian was responsible for swabbing the animal for the sample. All animals were handled with care. We transported the samples using a cooled envelope to the field laboratory within $4 \mathrm{~h}$ of collection. The specimens were stored in Cary Blair transport media and refrigerated at $-4{ }^{\circ} \mathrm{C}$. The samples were sent weekly to Lima for laboratory analysis. 


\section{Environmental Samples}

Water samples: We collected two water samples, one obtained from the child's main drinking water source-which could have been stored and/or home treated-and the second from the household's primary water source (i.e., the tap or outside standpipe). If the household only had one of the two potential types of water sources at the time of the visit, the available water source was collected twice. Water samples were also collected from the community water reservoir. The reservoir could supply more than one community.

All samples were transported back to the field station within $8 \mathrm{~h}$ of collection, and analysed using the membrane-filtration method of Oxfam DelAgua Water Testing Kit, product code 14867 [37].

Soil samples: We collected five shallow (less than $5 \mathrm{~cm}$ depth) soil samples of different random points ( $5 \mathrm{~g}$ of soil per sample) from the main playing area of the child (or from the area where the child spent the most time), using sterile metallic spoons. The samples were placed in labelled Ziplock sterile bags and transported back to the field station.

\subsubsection{Laboratory Analysis of Samples}

Human and animal samples: Enterobacteriaceae isolates were identified using CHROMagar Orientation (CHROMagar, France) and conventional microbiological methods according to Biochemical Tests for Identification of Medical Bacteria [38].

Water samples (reservoir and drinking water samples) were analysed for thermotolerant (faecal) coliforms using the membrane-filtration method of the Oxfam DelAgua Water Testing Kit. We incubated the samples at $44^{\circ} \mathrm{C} \pm 0.5^{\circ} \mathrm{C}$, from 14 to $16 \mathrm{~h}$ in lauryl sulphate broth. Samples were evaluated according to the kit's instructions, counting the yellow colonies forming units (CFU) in the first $15 \mathrm{~min}$ as indicative of thermotolerant bacterial growth. We stored colonies with similar morphology in peptone media vials and sent the vials weekly to Lima for the antibiotic susceptibility testing and ESBL detection and molecular confirmation.

Soil samples were homogenised in the San Marcos field station, and $1 \mathrm{~g}$ of each sample was transferred to Luria Bertani Broth $(25 \mathrm{~mL})$. The samples were incubated at $37^{\circ} \mathrm{C}$ for $24 \mathrm{~h}$, stored at $4{ }^{\circ} \mathrm{C}$ and were sent weekly to Lima for the antibiotic susceptibility testing and ESBL detection and molecular confirmation.

\section{Antibiotic Susceptibility Testing}

The antibiotic resistance pattern was determined against fourteen antibiotics using the Kirby-Bauer disk diffusion method following the Clinical and Laboratory Standards Institute (CLSI) guidelines [39]: nalidixic acid (30- $\mu$ g disk), ciprofloxacin (5- $\mu \mathrm{g}$ disk), chlo-

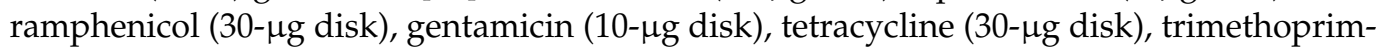
sulfamethoxazole (25- $\mu \mathrm{g}$ disk), amoxicillin-clavulanic acid (30- $\mu \mathrm{g}$ disk), ampicillin (10- $\mu \mathrm{g}$

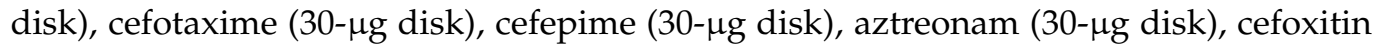

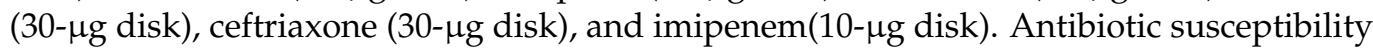
testing was performed for all isolated bacteria.

\section{Extended Spectrum Beta Lactamases (ESBL) Detection and Confirmation}

Phenotypic detection of ESBL bacteria: Antibiotic susceptibilities for all bacterial isolates were tested using the Jarlier method [40] for the following antibiotics: aztreonam (5- $\mu \mathrm{g}$ disk), ceftazidime (30- $\mu \mathrm{g}$ disk), cefotaxime (30- $\mu \mathrm{g}$ disk), ceftriaxone (30- $\mu \mathrm{g}$ disk),

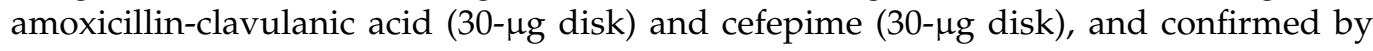
combined disks.

Molecular confirmation of ESBL genes: E. coli isolates displaying phenotypic ESBL activity were tested by conventional polymerase chain reaction (PCR) to identify the genes $b l a_{T E M}, b l a_{S H V}$, and $b l a_{C T X-M}[41-44]$. Within the $b l a_{C T X-M}$ group, the following subgroups were determined: $b l a_{C T X-M-2}, b l a_{C T X-M-3}, b l a_{C T X-M-8}, b l a_{C T X-M-9}$, and $b l a_{C T X-M-10}$. The primers used are shown in Supplementary Table S1. Identified ESBL genes were not sequenced for allelic variants. 


\subsubsection{Questionnaires}

We created and applied a questionnaire that considered the One Health approach to identify the transmission pathways to explain AMR dissemination. Trained fieldworkers applied the questionnaire to collect information on AMR dissemination pathways, household hygiene practices, household water management, recent antibiotic use by household members, animal management, and agricultural practices to identify routes for the spread of AMR in rural settings.

\subsection{Data Analysis}

The data was entered in the Census and Survey Processing System (CS Pro 6.3) and exported to Stata 15 Statistical software (STATA CORP, College Station, TX, USA) for analysis. We carried out a descriptive analysis, and compared the frequencies of AMR bacterial types between human, animal, and environmental sources. We assessed AMR patterns identified in the household drinking water samples and animal samples from the same site and water sources from the area.

\subsection{Ethics}

Human (418-16-18) and Animal (010-03-20) ethical review boards from the Universidad Peruana Cayetano Heredia approved the study. Each participant signed a written informed consent, agreeing to participate in our study.

\section{Results}

\subsection{AMR Dissemination Pathways in Rural Settings}

Using the One Health approach, we tried to establish a AMR bacteria dissemination pathway, and evaluated how the AMR bacteria could spread, and how AMR drivers would prompt the dissemination in Cajamarca's rural setting (Figure 1). We found evidence for specific pathways, and these are represented in red solid lines in Figure 1.

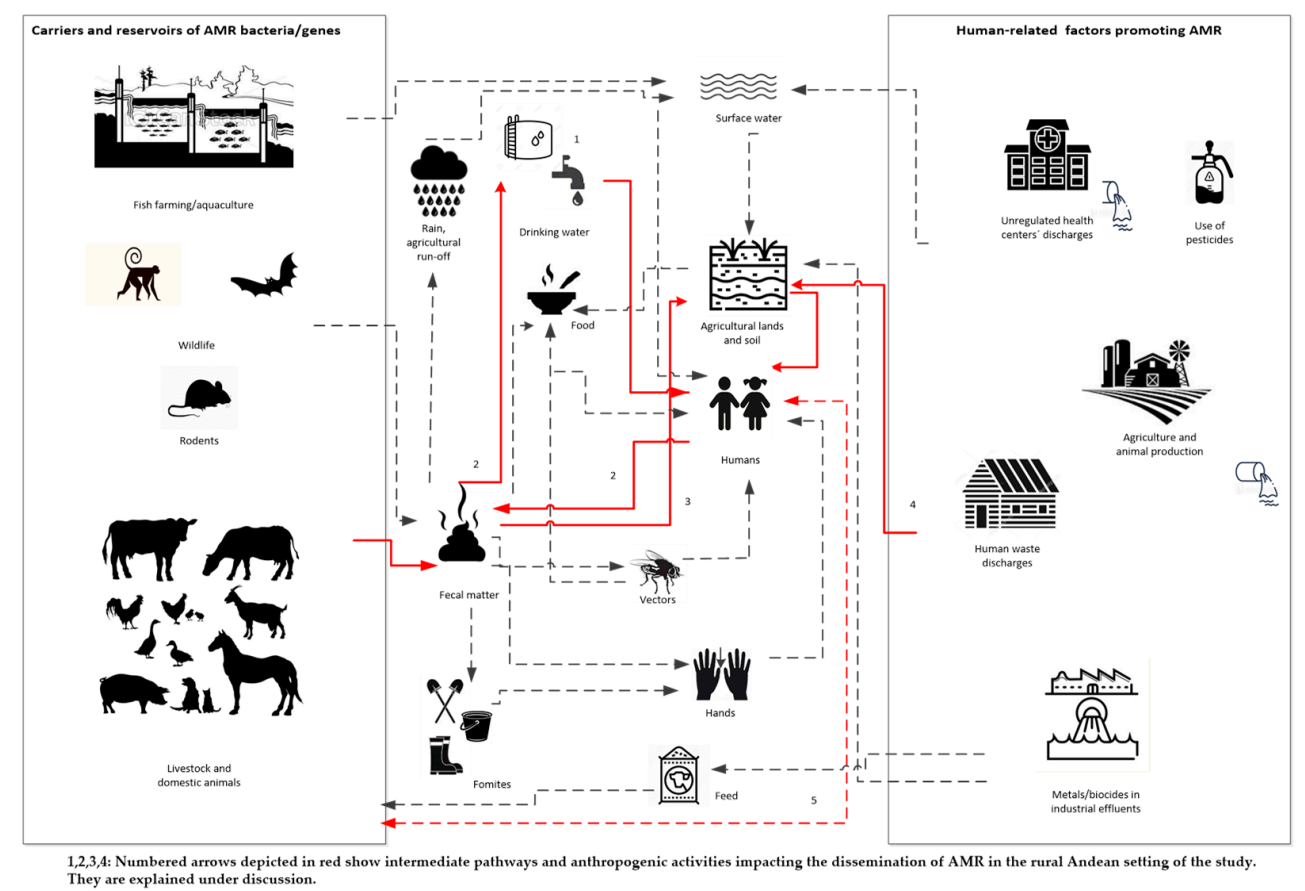

Figure 1. Identified dissemination pathways in Peruvian rural settings applying a One Health lens.

\subsection{Setting Description}

The main demographics, household's characteristics, household's water treatment, and animal management and treatment, are found in Table $1.72 .5 \%$ of homes had access to a piped water system and $20 \%$ to the yard or household premises. Both systems are 
a gravity-based piped water supply system. For drinking water, $27.5 \%$ of participants consumed water directly from the faucet without any treatment, $60 \%$ declared boiling the water and a small proportion (12.5\%) reported treating the water with chlorine or bleach. For animal handling and treatment, $72.5 \%$ of the households responded that they received antibiotics as part of their last treatment. The main antibiotic brands used were "Ciclosona" (50\%) and "Biomizona" (21.8\%), both containing oxytetracycline and an anti-inflammatory drug. More than $80 \%$ of the homes reported that they got the antibiotics from a veterinary doctor, technician, or a local veterinary store.

Table 1. Descriptive statistics of households' demographic characteristics, water supply and treatment, animal keeping.

\begin{tabular}{|c|c|c|}
\hline & $\mathbf{N}$ & Mean $[S D]$ or $\%(N)$ \\
\hline Demographic characteristics & 40 & \\
\hline Number of inhabitants per household & & $5.0[1.44]$ \\
\hline Number of children under 6 per household & & $1.4[0.53]$ \\
\hline \multicolumn{3}{|l|}{ Household characteristics } \\
\hline $\begin{array}{l}\text { Adobe wall type } \\
\text { - Coated adobe or rammed earth } \\
\text { - Uncoated adobe or rammed earth }\end{array}$ & & $\begin{array}{l}60(24) \\
22.5(9)\end{array}$ \\
\hline $\begin{array}{l}\text { Latrines w/o ventilation } \\
\text { - Septic tank } \\
\text { - Latrine }\end{array}$ & & $\begin{array}{l}22.5(9) \\
75(30)\end{array}$ \\
\hline $\begin{array}{l}\text { Piped water supply } \\
\text { - Public water supply system/piped water in the house } \\
\text { - Public water supply system/piped water outside the house } \\
\text { - Public water supply system/piped water outside the house but inside the building } \\
\text { - Surface water, spring }\end{array}$ & & $\begin{array}{c}72.5(29) \\
20(8) \\
2.5(1) \\
5(2)\end{array}$ \\
\hline $\begin{array}{l}\text { Energy source } \\
\text { - Electricity } \\
\text { - Candle } \\
\text { - Solar Panel }\end{array}$ & & $\begin{array}{c}87.5(35) \\
5(2) \\
7.5(3)\end{array}$ \\
\hline Household Water Treatment & & \\
\hline Boiling & & $60(24)$ \\
\hline Chlorine or bleach & & $12.5(5)$ \\
\hline None & & $27.5(11)$ \\
\hline Animal Management and treatment & & \\
\hline The last time the animal was treated; did the animal receive any antibiotic? & & $72.5(29)$ \\
\hline $\begin{array}{l}\text { Antibiotic used for the treatment } \\
\text { - Amoxicillin } \\
\text { - "Biomizona" } 1 \\
\text { - "Ciclosona" } 2 \\
\text { - "Emicina" } 3 \\
\text { - "Hipradoxi S" } 4 \\
\text { - "Hipralona" } 5 \\
\text { - "Quinolaba" } 5 \\
\text { - "Tylogen" } 6\end{array}$ & & $\begin{array}{l}3.1(1) \\
21.8(7) \\
50(16) \\
3.1(1) \\
3.1(1) \\
6.2(2) \\
6.2(2) \\
6.2(2)\end{array}$ \\
\hline
\end{tabular}


Table 1. Cont.

\begin{tabular}{lc}
\hline & N \\
\hline Where did they get the antibiotic? & Mean [SD] or \% (N) \\
- Directly form a veterinarian & $18.7(6)$ \\
- Directly from a veterinarian technician & $50(16)$ \\
- From a neighbour or relative & $3.1(1)$ \\
- At a local veterinary store & $18.7(6)$ \\
- At a veterinary store in the area & 0 \\
- At a pharmacy & 0 \\
- Other place & $9.3(3)$ \\
\hline
\end{tabular}

${ }^{1}$ Brand name for a commercial formulation of oxytetracycline and benzydamine, ${ }^{2}$ brand name for a commercial formulation of oxytetracycline and dexamethasone, ${ }^{3}$ brand name for oxytetracycline, ${ }^{4}$ brand name for doxycycline, ${ }^{5}$ brand names for enrofloxacin, ${ }^{6}$ brand name for a commercial formulation of Gentamicin and Tylosin.

\subsection{Water Samples}

In total, we collected 106 water samples, 26 from the reservoir, 40 from the main's household water source, and 40 from the child's drinking water source. As shown in Table 2, nine out of the 26 water reservoir samples (34.6\%) were positive for thermotolerant coliforms. From these positive samples, we obtained a total of 14 bacteria isolates, and $92.8 \%$ were positive for $E$. coli. For the main household water samples (collected from faucet or pitcher), 18 out of 40 (45\%) were positive for thermotolerant coliforms. We obtained a total of 28 thermotolerant bacterial isolates, and $82.1 \%$ of them were Enterobacteriaceae. Of the enterobacteria isolates, $57.1 \%$ were E. coli, $10.7 \%$ Klebsiella spp. and $14.8 \%$ were Enterobacter spp. Thirteen out of the 40 (32.5\%) child's drinking water samples were positive for thermotolerant coliforms, and a total of 27 thermotolerant bacteria were isolated from these positive samples. Enterobacteriaceae represented $74 \%$ of all the isolates, and $44.4 \%$ of the enterobacteria isolates were E. coli, $14.8 \%$ were Klebsiella spp. and $14.2 \%$ Enterobacter spp. (Table 2).

Table 2. Descriptive statistics of bacterial contamination, frequency and type of thermotolerant coliform identified from all water sources.

\begin{tabular}{|c|c|c|c|}
\hline Coliforms (Count) & $\begin{array}{l}\text { Water from Reservoir } \\
(\mathrm{N}=26) \\
\%(\mathrm{~N})\end{array}$ & $\begin{array}{c}\text { Main Household's Water } \\
(\mathrm{N}=40) \\
\%(\mathrm{~N})\end{array}$ & $\begin{array}{l}\text { Child's Drinking Water } \\
(\mathbf{N}=40) \\
\%(N)\end{array}$ \\
\hline $\begin{array}{l}\text { Thermotolerant coliform count } \\
\text { (IQR 1st-3rd Quantile) }\end{array}$ & $0-3.75$ & $0-10.5$ & $0-9.5$ \\
\hline $\begin{array}{l}\text { Thermotolerant coliform } \\
\text { (CFU/mL)-mean (SD) }\end{array}$ & $14.3(59.2)$ & $36.2(108.4)$ & $104.1(373.5)$ \\
\hline $\begin{array}{l}\text { Total positive thermotolerant } \\
\text { sample }\end{array}$ & $34.6(9)$ & $45(18)$ & $32.5(13)$ \\
\hline $\begin{array}{l}\text { Total thermotolerant bacterial } \\
\text { isolates * }\end{array}$ & $\begin{array}{l}\mathrm{N}=14 \\
\%(\mathrm{n})\end{array}$ & $\begin{array}{l}\mathrm{N}=28 \\
\%(\mathrm{n})\end{array}$ & $\begin{array}{l}\mathrm{N}=27 \\
\%(\mathrm{n})\end{array}$ \\
\hline $\begin{array}{l}\text { Total positive } \\
\text { Enterobacteriaceae isolates }\end{array}$ & $92.8(13)$ & $82.1(23)$ & $74.0(20)$ \\
\hline E. coli & $92.8(13)$ & $57.1(16)$ & $44.4(12)$ \\
\hline Klebsiella spp. & 0 & $10.7(3)$ & $14.8(4)$ \\
\hline Enterobacter spp. & 0 & $14.8(4)$ & $14.2(4)$ \\
\hline
\end{tabular}

* Correspond only to the positive enterobacteria isolates. 
We determined the phenotypic antibiotic resistance profile for Escherichia coli and Klebsiella spp. isolates. From the 13 E. coli isolates found in the reservoir's water, $30.8 \%$ displayed resistance to at least one antibiotic. The E. coli antibiotic profile showed the highest resistance to tetracycline. All Klebsiella spp. isolates from the main household's water and child's drinking water displayed resistance to at least one antibiotic, showing the highest resistance to ampicillin. Multidrug resistance was displayed in 33.3\% and $25 \%$ of the Klebsiela spp. isolates for the main household's water and child's drinking water, respectively (Table 3). E. coli also showed the highest resistance towards tetracycline $(31.3 \%)$, ampicillin and nalidixic acid (18.8\%) in the main household's water source. We found the highest resistance to tetracycline (41.6\%) and ampicillin (25\%) in the child's drinking water source (Table 3).

Table 3. Escherichia coli and Klebsiella spp. antibiotic resistance profile to a panel of antibiotics, water type (reservoir, main household water source, child drinking water), and proportion of multidrug-resistant isolates.

\begin{tabular}{|c|c|c|c|c|c|}
\hline & \multirow{2}{*}{$\begin{array}{c}\text { Water from Reservoir } \\
\begin{array}{c}\text { E. coli } \\
\mathrm{N}=13\end{array}\end{array}$} & \multicolumn{2}{|c|}{ Main Household's Water } & \multicolumn{2}{|c|}{ Child's Drinking Water } \\
\hline & & $\begin{array}{l}\text { E. coli } \\
\mathrm{N}=16\end{array}$ & $\begin{array}{l}\text { Klebsiella spp. } \\
\quad \mathrm{N}=3\end{array}$ & $\begin{array}{l}\text { E. coli } \\
\mathrm{N}=12\end{array}$ & $\begin{array}{l}\text { Klebsiella spp. } \\
\quad \mathbf{N}=4\end{array}$ \\
\hline Antibiotic & $\begin{array}{l}\text { Resistance } \\
\%(\mathrm{~N})\end{array}$ & \multicolumn{2}{|c|}{$\begin{array}{c}\text { Resistance } \\
\%(\mathrm{~N})\end{array}$} & \multicolumn{2}{|c|}{$\begin{array}{c}\text { Resistance } \\
\%(\mathrm{~N})\end{array}$} \\
\hline Amoxicillin-clavulanic acid & 0 & 0 & 0 & 0 & 0 \\
\hline Ampicillin & 0 & $18.8(3)$ & $100(3)$ & $25(3)$ & $100(4)$ \\
\hline Aztreonam & 0 & 0 & 0 & 0 & 0 \\
\hline Cefotaxime & $15.4(2)$ & 0 & 0 & $8.3(1)$ & 0 \\
\hline Cefoxitin & 0 & 0 & 0 & 0 & 0 \\
\hline Chloramphenicol & $7.7(1)$ & $12.5(2)$ & 0 & $25(3)$ & 0 \\
\hline Ciprofloxacin & 0 & $6.3(1)$ & $33.3(1)$ & $16.7(2)$ & $25(1)$ \\
\hline Gentamicin & 0 & $6.3(1)$ & 0 & $8.3(1)$ & 0 \\
\hline Nalidixic acid & 0 & $18.8(3)$ & 0 & $16.7(2)$ & 0 \\
\hline $\begin{array}{l}\text { Trimethoprim- } \\
\text { sulfamethoxazole }\end{array}$ & 0 & 0 & $33.3(1)$ & $8.3(1)$ & $25(1)$ \\
\hline Tetracycline & $15.4(2)$ & $31.3(5)$ & $33.3(1)$ & $41.7(5)$ & $25(1)$ \\
\hline Ceftriazone & 0 & 0 & 0 & $11.1(1)$ & 0 \\
\hline Cefepime & 0 & 0 & 0 & $8.3(1)$ & 0 \\
\hline Imipenem & 0 & 0 & 0 & 0 & 0 \\
\hline AMR to at least one antibiotic ${ }^{1}$ & $30.8(4)$ & $43.8(3)$ & $100(3)$ & $41.7(5)$ & $100(4)$ \\
\hline Multidrug resistance $^{2}$ & $0(0)$ & $18.6(3)$ & $33.3(1)$ & $33.3(4)$ & $25(1)$ \\
\hline
\end{tabular}

${ }^{1}$ Antimicrobial resistance (AMR) is defined as "the ability of a microorganism to stop an antimicrobial from working against it. As a result, standard treatments become ineffective; infections persist and may spread to others" [45]. ${ }^{2}$ Multidrug resistance is defined as resistance to three or more classes of antibiotics [46].

\subsection{Soil Samples}

All soil was positive for thermotolerant coliforms. We obtained 83 isolates from the samples. Of these, $43.3 \%$ were identified as E. coli, $4.8 \%$ Klebsiella spp., $24.1 \%$ Enterobacter spp. and $9.6 \%$ Citrobacter spp. (Table 4 ). 
Table 4. Bacterial contamination by frequency and type of thermotolerant coliform in household and agricultural soil and animal and human feces.

\begin{tabular}{cccc}
\hline Coliforms & $\begin{array}{c}\text { Soil } \\
(\mathbf{N}=\mathbf{4 0 )} \% \mathbf{( n )}\end{array}$ & $\begin{array}{c}\text { Child Faeces } \\
\mathbf{( N = 4 0 )} \% \mathbf{( n )}\end{array}$ & $\begin{array}{c}\text { Animal Faeces } \\
\mathbf{( N = 8 0 )} \% \mathbf{( n )}\end{array}$ \\
\hline $\begin{array}{c}\text { Thermotolerant } \\
\text { coliforms }\end{array}$ & $100(40)$ & $97.5(39)$ & $67.5(54)$ \\
\hline $\begin{array}{c}\text { Total thermotolerant } \\
\text { bacterial isolates }\end{array}$ & $\begin{array}{c}\mathrm{N}=83 \\
\%(\mathrm{n})\end{array}$ & $\begin{array}{c}\mathrm{N}=98 \\
\%(\mathrm{n})\end{array}$ & $\begin{array}{c}\mathrm{N}=116 \\
\%(\mathrm{n})\end{array}$ \\
\hline E. coli & $43.3(36)$ & $45.3(44)$ & $38.7(45)$ \\
\hline Klebsiella spp. & $4.8(4)$ & $11.3(11)$ & $5.1(6)$ \\
\hline Enterobacter spp. & $24.1(20)$ & $6.2(6)$ & $4.3(5)$ \\
\hline Citrobacter spp. & $9.6(8)$ & $9.2(9)$ & $16.3(19)$ \\
\hline
\end{tabular}

Some 36 E. coli isolates were found in the soil samples of which $33.3 \%$ displayed resistance to at least one antibiotic and one showed multidrug resistance. From the Klebsiella spp. isolates, $75 \%$ displayed resistance to at least one antibiotic, but no multidrug resistance was observed. The E. coli antibiotic profile displayed highest resistance to tetracycline (25\%) and ampicillin (11.1\%), and Klebsiella spp. showed the highest resistance to ampicillin (Table 5).

Table 5. Escherichia coli and Klebsiella spp. antibiotic resistance profile to a panel of antibiotics, per sample type (soil, child and animal feces), and proportion of multidrug-resistant isolates.

\begin{tabular}{|c|c|c|c|c|c|c|}
\hline & \multicolumn{2}{|c|}{ Soil } & \multicolumn{2}{|c|}{ Child Faeces } & \multicolumn{2}{|c|}{ Animal Faeces } \\
\hline & $\begin{array}{l}\text { E. coli } \\
\mathrm{N}=36\end{array}$ & $\begin{array}{l}\text { Klebsiella spp. } \\
\quad \mathrm{N}=4\end{array}$ & $\begin{array}{l}\text { E. coli } \\
\mathrm{N}=44\end{array}$ & $\begin{array}{l}\text { Klebsiella spp. } \\
\quad \mathrm{N}=11\end{array}$ & $\begin{array}{l}\text { E. coli } \\
\mathrm{N}=45\end{array}$ & $\begin{array}{l}\text { Klebsiella spp. } \\
\quad \mathrm{N}=6\end{array}$ \\
\hline Antibiotic & \multicolumn{2}{|c|}{$\begin{array}{l}\text { Resistance } \\
\%(\mathrm{~N})\end{array}$} & \multicolumn{2}{|c|}{$\begin{array}{l}\text { Resistance } \\
\%(\mathrm{~N})\end{array}$} & \multicolumn{2}{|c|}{$\begin{array}{c}\text { Resistance } \\
\%(\mathrm{~N})\end{array}$} \\
\hline Amoxicillin-clavulanic acid & 0 & $25(1)$ & 0 & $9.1(1)$ & $4.4(2)$ & 0 \\
\hline Ampicillin & $11.1(4)$ & $75(3)$ & $34.1(15)$ & $54.5(6)$ & $11.1(5)$ & $50(3)$ \\
\hline Aztreonam & 0 & 0 & $2.3(1)$ & 0 & $2.2(1)$ & 0 \\
\hline Cefotaxime & 0 & 0 & 0 & 0 & 0 & 0 \\
\hline Cefoxitin & $2.8(1)$ & $25(1)$ & 0 & $9.1(1)$ & $4.4(2)$ & 0 \\
\hline Chloramphenicol & $2.8(1)$ & 0 & $4.5(2)$ & 0 & $11.1(5)$ & 0 \\
\hline Ciprofloxacin & $5.5(2)$ & 0 & $11.4(5)$ & 0 & $8.8(4)$ & 0 \\
\hline Gentamicin & 0 & 0 & $2.3(1)$ & 0 & 0 & 0 \\
\hline Nalidixic acid & $5.5(2)$ & 0 & $13.6(6)$ & 0 & $20(9)$ & 0 \\
\hline $\begin{array}{l}\text { Trimethoprim- } \\
\text { sulfamethoxazole }\end{array}$ & $5.5(2)$ & 0 & $20.5(9)$ & $9.1(1)$ & $11.1(5)$ & 0 \\
\hline Tetracycline & $25.0(9)$ & 0 & $25.0(11)$ & $9.1(1)$ & $26.6(12)$ & 0 \\
\hline Ceftriazone & 0 & 0 & $2.3(1)$ & 0 & 0 & 0 \\
\hline Cefepime & 0 & 0 & 0 & 0 & 0 & 0 \\
\hline Imipenem & 0 & 0 & 0 & 0 & 0 & 0 \\
\hline $\mathrm{AMR}^{1}$ & $33.3(12)$ & $75(3)$ & $52.3(23)$ & $54.6(6)$ & 37.7 (17) & $50(3)$ \\
\hline $\mathrm{MDR}^{2}$ & $2.8(1)$ & $0(0)$ & $15.9(7)$ & $0(0)$ & $0(0)$ & $0(0)$ \\
\hline
\end{tabular}




\subsection{Child Fecal Samples}

$97.5 \%$ of the child fecal samples were positive for thermotolerant coliforms (Table 4). We obtained a total of 98 thermotolerant bacteria isolates. Of these, almost half of the samples had E. coli (45.3\%), followed by Klebsiella spp. (11.3\%), Citrobacter spp. (9.2\%) and Enterobacter spp. (6.2\%).

We carried out antibiotic resistance profiling for Escherichia coli and Klebsiella spp. isolates in the child fecal samples (Table 5). From all E. coli isolates, 52.3\% displayed resistance to at least one antibiotic and $15.9 \%$ were multidrug-resistant; $54.6 \%$ of the Klebsiella spp. isolates displayed resistance to at least one antibiotic, but we did not find multidrug resistance. The highest resistance for the $E$. coli isolates was to ampicillin $(34.1 \%)$ and tetracycline $(25.0 \%)$ and the highest resistance for Klebsiella spp. was to ampicillin (54.5\%).

\subsection{Animal Fecal Samples}

Of the 80 animal fecal samples, $67.5 \%$ were positive for thermotolerant coliforms. We obtained a total of 116 thermotolerant bacteria isolates, and they were identified as E. coli (38.7\%), Klebsiella spp. (5.1\%), Citrobacter spp. (16.3\%) and Enterobacter spp. (4.3\%) (Table 4).

We performed antibiotic resistance profiling for Escherichia coli, Klebsiella spp. Citrobacter spp. and Enterobacter spp. in the isolates. From the isolates 37.7\% of E. coli, 50\% of Klebsiella spp. and $60 \%$ of the Enterobacter spp. isolates displayed resistance to at least one antibiotic. None were multidrug-resistant (Table 5).

\subsection{Multidrug Resistance Profiles}

Among the E. coli isolates obtained from the child's feces, child's drinking water source, household's main water source and soil, $13.9 \%(15 / 108)$ were resistant to three or more classes of antibiotics [46]. Most of them were resistant to ampicillin, trimethoprimsulfamethoxazole, tetracycline, nalidixic acid, and ciprofloxacin. Only one isolate of E. coli was identified as a carrier of ESBL (Table 6).

Table 6. Profile of all multidrug-resistant E. coli isolates from different sources.

\begin{tabular}{ccc}
\hline Source Type *** & MDR & Antimicrobial Class ** \\
\hline Child Water & AMP, TE y C & Penicillin \\
Child Water & SXT, TE, C & Sulfonamides, tetracycline, quinolone \\
Child Water & NA, CIP y TE & Quinolone, tetracycline \\
Child Water & AMP, CTX, CRO, FEP, NA, CIP, TE, C y CN & Penicillin, 3rd \& 4th generation cephalosporin, quinolone, tetracycline \\
HH Water Source & NA, TE, C y CN & Quinolone, tetracycline \\
HH Water Source & NA, CIP, SXT, TE, C & Quinolone, sulfonamides, tetracycline \\
HH Water Source & AMP, SXT, TE & Penicillin, quinolone, tetracycline \\
Soil & AMP, NA, CIP, SXT, TE, C & Penicillin, quinolone, sulfonamides, tetracycline \\
Child faeces & AMP, NA, CIP, SXT, TE y CN & Penicillin, quinolone, sulfonamides, tetracycline \\
Child faeces & AMP, SXT, TE & Penicillin, sulfonamides, tetracycline \\
Child faeces & AMP, TE, C & Penicillin, tetracycline, quinolone \\
Child faeces & AMP, SXT, TE & Penicillin, sulfonamides, tetracycline \\
Child faeces & CRO, CIP, SXT & 3rd generation cephalosporin, quinolone, sulfonamides \\
Child faeces & AMP, SXT, TE & Penicillin, sulfonamides \\
Child faeces & AMP, NA, CIP, SXT, TE & Penicillin, quinolone, sulfonamides, tetracycline \\
\hline
\end{tabular}

AMP: ampicillin, STX: trimethoprim-sulfamethoxazole, NA: nalidixic acid, TE: tetracycline, CIP: ciprofloxacin, C: chloramphenicol, $\mathrm{CN}$ : gentamicin, CTX: cefotaxime, FEP: cefepime and CRO: ceftriaxone. * E. coli isolates harboring ESBL, ${ }^{* *}$ as per WHO antimicrobial class classification. ${ }^{* * *} \mathrm{HH}$ : household.

\subsection{Detection of ESBL Resistance Genes}

We identified two bacterial isolates harbouring ESBL genes. One was an E. coli isolate from a water sample, and one was a Shigella spp. isolate from a dog faecal sample. The ESBL E. coli isolate carried the $b l a_{T E M}, b l a_{C T X-M-U}$, and $b l a_{C T X-M-8}$ genes; and the ESBL Shigella spp. isolate carried the $b l a_{T E M}, b l a_{C T X-M-U}$, and bla $a_{C T X-M-3}$ genes. PCR amplification of $\beta$-lactamase genes for both samples are found in Supplementary Figure S1. 


\section{Discussion}

Our study is among the first to investigate specific aspects related to AMR's spread in the Andean region in Peru. Adopting the One Health lens provided a unique and important insight into the complex, interlinked problem between human, animal, and environment health [47].

Our results provide descriptive evidence for the pathways shown in red in Figure 1. AMR thermotolerant bacteria-mainly E. coli-were found in children's stools and animal faeces, and they were also detected in the reservoir water, the household's and child's drinking water sources; as well as in the soil from the household's yard. For all the samples, the prevalence of resistance to at least one antibiotic in the E. coli and Klebsiella spp. isolates was almost $43 \%$ and the prevalence of MDR in the same isolates was nearly $9 \%$, yet the latter nearly doubled (15.9\%) in children's stools.

Our finding of thermotolerant coliforms in the reservoir's water indicates recent fecal contamination [48]. $34.6 \%$ of reservoir water samples were positive for thermotolerant coliforms, with counts above the Peruvian and WHO threshold guidelines (0 CFU in $100 \mathrm{~mL}$ ) $[48,49]$. We provide two likely explanations for these findings. Poor reservoir infrastructure and/or the distribution network results in contamination, possibly with animal faeces. In Peruvian rural Andean settings, about $30 \%$ of water storage and supply systems are older than 20 years, and some $20 \%$ have collapsed [50]. Another potential explanation is that agricultural run-off, rain, surface or underground water containing animal or human fecal matter seep into the system [48,51]. Further, inadequate water supply management, infrequent cleaning or disinfection, irregular treatment (automated chlorination systems or manual chlorination) of the reservoir, and/or the lack of a maintenance backlog and the use of old materials are also frequent concerns [50,52]. According to the Peruvian Ministry of Housing, Construction and Sanitation [50], only 6.9\% of water storage and supply facilities apply proper treatment guaranteeing water safety in rural Peru. In all Cajamarca, including the San Marcos Province, reservoirs do not have an automated disinfection system; most use manual chlorination and are managed unreliably by the community water supply and irrigation committees (JASS) [52]. In fact, an earlier study in the same area found that the spring water stored at the reservoir was unfiltered, untreated, and chlorination was performed infrequently [53]. Given that $27.3 \%$ of all E. coli isolates from the reservoirs' water displayed AMR and had faecal origin, the water distribution network could play an important role in spreading AMR in the population (See Figure 1, pathway 1).

In the households, we found that $25 \%$ of the households' heads reported consuming water directly from the faucet or bucket without any previous household water treatment (HWT), exposing residents to potential contamination in case of failures in the central water treatment facility. Most households reported boiling or adding chlorine as their preferred HWT methods; however, it is most likely that the real proportion of homes treating their water regularly is much lower, based on the findings of this study and previous ones from the area [35]. We found that nearly half of the household water samples were positive for thermotolerant coliforms, and of the $57.1 \%$ E. coli isolates, $18.6 \%$ showed multidrug resistance. It is not clear whether the home-treated water is being recontaminated from bacteria found within the household environs or the recontamination is caused by inadequate storage. However, it could also be due to poor hygienic practices in the household, lack of handwashing, and free-roaming animals and vectors. Thus, the AMR bacterial isolates in drinking water could originally come from human or animal waste [54], as shown in pathway 2, Figure 1.

We found that the AMR profiles show a relationship with the most commonly used antibiotics in the area. Oxytetracycline was the most common antibiotic used for animal treatment reported by the household head. Coincidently, the highest resistance for the E. coli isolates in animals' faeces was tetracyclines, and similar resistance profiles were observed in all the water samples (reservoir and drinking water samples). This underscores the hypothesis that faeces are contaminating water within the water delivery system. Tetracyclines are a family of antibiotics widely used in veterinary medicine and animal 
production; compared to other antibiotics used in livestock farming, they are applied in greater amounts and tend to persist in the environment for longer periods [55]. Tetracycline use and resistance have been reported in other rural environments with animal production activity $[26,56,57]$. Children's drinking water samples also displayed resistance to ampicillin, which is the most common antibiotic used in the area for treating childhood illnesses. This indicates that treated drinking water for children's consumption could be recontaminated with children's feces due to mismanagement and poor personal hygiene within the home (Figure 1, pathway 2).

Multidrug-resistant and thermotolerant coliform bacteria were prevalent in the study area. We found that one third of all E. coli isolates from the child's drinking water were positive for MDR. According to the WHO list of critically important antimicrobials classification, third and fourth generation cephalosporins, quinolones and tetracycline in the child's drinking water could indicate a severe public health risk for children in rural areas, given the lack of treatment options for multidrug-resistant infections. Multidrug resistance in coliforms is escalating worldwide, and it may be explained by their high tendency to transfer and receive AMR genes horizontally [58]. In a recent study in the rural Andean regions of Peru, Larson et al. [17] found a lower percentage (19.7\%) but still alarming frequency of multidrug resistant $E$. coli in children's drinking water just four years ago. It is unclear whether the propagation of resistant bacteria and/or the spread of AMR genes are rising in this rural area. The higher percentage of MDR bacteria found among E. coli isolates and bacteria carrying ESBL genes (bla $a_{T E M}, b l a_{C T X-M-U}$ and $\left.b l a_{C T X-M-8}\right)$ in children's drinking water compared to the main household water, could be due to poor water treatment and hygiene practices, inappropriate use (unpublished data) or contaminated storage containers [59]. Nearly 59\% of the households that reported treating their water, also reported storing it in different types of containers; the use of wide-mouth containers increased the possibility of recontamination (unpublished data). Similar findings are described in a study investigating drinking water samples in rural households in Ecuador [60].

The high prevalence of thermotolerant coliforms found in the soil indicates significant fecal contamination, given that most animals roam freely in the courtyard and in the community. Evidence shows that in rural areas, soil fecal contamination is mainly attributed to animals [61,62]. The environs of family households and farms may be more affected by AMR due to the presence of animal manure. In many cases, animal manure is used to fertilize crops, increasing the chances of AMR spread to farmland and produce [56]. The prevalence of resistance to any antibiotic in E. coli and Klebsiella spp. in animal faeces was $37.7 \%$ and $50 \%$, whereas in soil it was 33.3\% and 75\%, respectively, supporting pathway 3 in Figure 1. The finding of ESBL genes $\left(b l a_{T E M}\right.$, and bla $\left.a_{C T X-M-3}\right)$ on an Shigella spp. isolate from a dog illustrates the importance of strengthening surveillance programmes for MDR to gain a better understanding of community source dissemination. Given that humans are Shigella spp. main reservoir [63], its finding in a dog flags the possibility of transmission from humans to animals (pathway 5, Figure 1). We found evidence in South America of the presence of E. coli carrying ESBL genes in dog feces in public parks [64]. Another possible source of soil contamination is water run-offs from poorly designed and poorly maintained pit latrines. Fifty-three percent of the households in the study area own and use pit latrines [36]. Pit latrines seep nightsoil into the ground and potentially contribute to the propagation of AMR bacteria in the environment [65]. Pathway 4 in Figure 1 seems plausible, given that in children's stools the prevalence of resistance to any antibiotic in E. coli and Klebsiella spp. was 52.3\% and 54.6\%, respectively. The finding of multidrug resistance in $15.9 \%$ of all E. coli isolates from the children's faeces indicates a high public health risk and calls for AMR surveillance to control the exposure to AMR bacteria in rural Andean settings like ours. However, no ESBL genes were found in these samples. 


\section{Limitations}

By intentionally focusing on studying AMR high-level households, we biased our estimates to be higher than what could potentially be expected in the average community.

Nevertheless, this decision allowed us to establish the principal pathways of transmission. We must assume that in less contaminated communities, those routes pertain as well and contribute to the AMR problem, but, due to their low numbers, they are difficult to detect.

\section{Conclusions}

The AMR problem in Peru is still largely underexplored, especially in rural regions. Using a One Health perspective to identify transmission pathways for AMR and acknowledging the convergence of animal, human, and environment health dimensions in the spread, we identified critical pathways of infection for rural settings. Our epidemiological findings demonstrate the interconnectedness of animal, human and environmental transmission. However, molecular analysis is needed to elucidate if the isolates found in each type of sample are clones, proving that the same AMR bacteria strains are shared. The high prevalence of AMR and MDR bacteria in children, soil, and water samples is alarming. Specifically for animal and child feces, we found that the resistance profiles seem to relate to the antibiotics most commonly used for treatment. This poses a critical public health threat as it can limit the use of these first line drugs in future. Drinking water is a neglected potential source of community exposure to antibiotic-resistant organisms. The presence of ESBL genes in drinking water and animal faeces samples show the anthropogenic origins of AMR. A standard microbiological water quality testing and management is needed and where protocols for the management and specific treatment of delivery networks exist, they need to be reinforced to reduce the current risk exposure to these harmful pathogens.

Supplementary Materials: The following supplementary files are available online at: https://www. mdpi.com/article/10.3390/ijerph18094604/s1. Table S1: Primers used for the detection of genes encoding the production of ESBL. Figure S1: PCR amplification of $\beta$-lactamase genes harboring blaTEM, blaCTX-M-8 and blaCTX-M-3 genes in Shigella spp. (S1) isolate from a dog faecal sample and E. coli (S2) isolate from a water sample. L, 100 bp DNA ladder, C-, negative control, $\mathrm{C}+$, positive control. (A) blaTEM (1150 bp), (B) blaCTX-M-3 (1017 bp), (C) blaCTX-M-8 (800 bp) amplification products.

Author Contributions: Conceptualization, S.M.H. and D.M.; methodology, S.M.H., A.J.L. and D.M.; data collection and lab analysis: M.P.-B. and M.R.; writing-original draft preparation, S.M.H. and M.L.M.-P.; analysis, H.V., G.S.-M. and S.M.H.; writing-review and editing, G.S.-M., M.L.M.-P., A.J.L., M.R. and D.M.; supervision, H.V., M.R. and D.M.; project administration, S.M.H. and D.M.; funding acquisition, S.M.H. and D.M. All authors have read and agreed to the published version of the manuscript.

Funding: This work was supported by the Novartis Foundation (grant number 18A059).

Institutional Review Board Statement: The study was conducted according to the guidelines of the Declaration of Helsinki, and approved by the Institutional Review Board for humans and animal subjects of the Universidad Peruana Cayetano Heredia, protocol code 418-16-18.

Informed Consent Statement: Informed consent was obtained from all subjects involved in the study.

Data Availability Statement: The data presented in this study are available on request from the corresponding author.

Acknowledgments: The authors would like to express their appreciation to the study families for their kind participation, our field staff and the local authorities for their continuous support. We also express our gratitude to the field coordinators, especially to Angélica Fernández and Raymi Alosilla for their unfailing support. Jordyn Wallenborn reviewed the article and provided valuable editorial assistance.

Conflicts of Interest: The authors declare that there is no conflict of interest regarding the publication of this paper. 


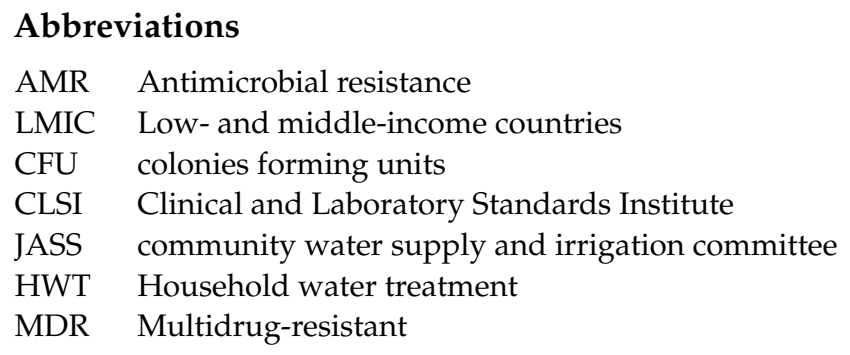

\section{References}

1. Pokharel, S.; Raut, S.; Adhikari, B. Tackling antimicrobial resistance in low-income and middle-income countries. BMJ Glob. Health 2019, 4, 4-6. [CrossRef]

2. Dadgostar, P. Antimicrobial resistance: Implications and costs. Infect. Drug Resist. 2019, 12, 3903-3910. [CrossRef]

3. World Health Organization. Global Action Plan on Antimicrobial Resistance; World Health Organization: Geneva, Switzerland, 2015; ISBN 9789241509763.

4. Ochoa, T.J.; Egoavil, M.; Castillo, M.E.; Reyes, I.; Chaparro, E.; Silva, W.; Campos, F.; Sáenz, A. Invasive pneumococcal diseases among hospitalized children in lima, Peru. Rev. Panam. Salud Publica/Pan Am. J. Public Health 2010, 28, 121-127. [CrossRef]

5. Pan American Health Organization. Tuberculosis in the Americas 2018 Regional Report; Pan American Health Organization: Washington, DC, USA, 2018.

6. Tien, V.; Punjabi, C.; Holubar, M.K. Antimicrobial resistance in sexually transmitted infections. J. Travel Med. 2020, 27, 1-11. [CrossRef] [PubMed]

7. Szmolka, A.; Nagy, B. Multidrug resistant commensal Escherichia coli in animals and its impact for public health. Front. Microbiol. 2013, 4, 1-13. [CrossRef]

8. Van Schaik, W. The human gut resistome. Philos. Trans. R. Soc. B 2015, 370, 20140087. [CrossRef]

9. Purohit, M.R.; Lindahl, L.F.; Diwan, V.; Marrone, G.; Lundborg, C.S. High levels of drug resistance in commensal E. coli in a cohort of children from rural central India. Sci. Rep. 2019, 9, 1-11. [CrossRef] [PubMed]

10. Pons, M.J.; Mosquito, S.; Gomesa, C.; Del Valle, L.J.; Ochoa, T.J.; Ruiz, J. Analysis of quinolone-resistance in commensal and diarrheagenic Escherichia coli isolates from infants in Lima, Peru. Trans. R. Soc. Trop. Med. Hyg. 2014, 108, 22-28. [CrossRef] [PubMed]

11. Miranda, J.; Pinto, J.; Faustino Arias, D.M.; Sánchez-Jacinto, B.; Ramirez, F. Antimicrobial resistance of uropathogens in older adults in a private clinic in Lima, Peru. Rev. Peru. Med. Exp. Salud Publica 2019, 36, 87-92. [CrossRef]

12. Marcos-Carbajal, P.; Galarza-Pérez, M.; Huancahuire-Vega, S.; Otiniano-Trujillo, M.; Soto-Pastrana, J. Comparación de los perfiles de resistencia antimicrobiana de Escherichia coli uropatógena e incidencia de la producción de betalactamasas de espectro extendido en tres establecimientos privados de salud de Perú. Biomédica 2020, 40, 139-147. [CrossRef] [PubMed]

13. Von Wintersdorff, C.J.H.; Penders, J.; Van Niekerk, J.M.; Mills, N.D.; Majumder, S.; Van Alphen, L.B.; Savelkoul, P.H.M.; Wolffs, P.F.G. Dissemination of antimicrobial resistance in microbial ecosystems through horizontal gene transfer. Front. Microbiol. 2016, 7,1-10. [CrossRef]

14. Pons, M.J.; Mosquito, S.; Ochoa, T.J.; Vargas, M.; Molina, M.; Lluque, A.; Gil, A.I.; Ecker, L.; Barletta, F.; Lanata, C.F.; et al. Niveles de resistencia a quinolonas y otros antimicrobianos en cepas de Escherichia coli comensales en niños de la zona periurbana de Lima, Perú. Rev. Peru. Med. Exp. Salud Publica 2012, 29, 82-86. [CrossRef]

15. Alzamora, M.C.; Echevarría, A.C.; Ferraro, V.M.; Riveros, M.D.; Zambruni, M.; Ochoa, T.J. Resistencia Antimicrobiana de cepas comensales de Escherichia coli en niños de dos comunidades rurales peruanas. Rev. Peru. Med. Exp. Salud Publica 2019, 36, 459-464. [CrossRef]

16. Kalter, H.D.; Gilman, R.H.; Moulton, L.H.; Cullotta, A.R.; Cabrera, L.; Velapatiño, B. Risk factors for antibiotic-resistant Escherichia coli carriage in young children in Peru: Community-based cross-sectional prevalence study. Am. J. Trop. Med. Hyg. 2010, 82, 879-888. [CrossRef] [PubMed]

17. Larson, A.; Hartinger, S.M.; Riveros, M.; Salmon-Mulanovich, G.; Hattendorf, J.; Verastegui, H.; Huaylinos, M.L.; Mäusezahl, D. Antibiotic-resistant Escherichia coli in drinking water samples from rural andean households in Cajamarca, Peru. Am. J. Trop. Med. Hyg. 2019, 100, 1-6. [CrossRef]

18. World Health Organization. Antimicrobial Resistance: An Emerging Water, Sanitation and Hygiene Issue; World Health Organization: Geneva, Switzerland, 2015.

19. Gonzáles Mendoza, J.; Maguiña Vargas, C.; de Gonzáles Ponce, F.M. Resistance to antibacterial agents: A serious problem. Acta Med. Peru. 2019, 36, 145-151. [CrossRef]

20. Organización Panamericana de la Salud. Plan de Accion Sobre la Resistencia a los Antimicrobianos; Organización Panamericana de la Salud: Washington, DC, USA, 2015.

21. World Health Organization. Antimicrobial Resistance: Global Report on Surveillance; World Health Organization: Geneva, Switzerland, 2014.

22. Palhares, J.C.P.; Kich, J.D.; Bessa, M.C.; Biesus, L.L.; Berno, L.G.; Triques, N.J. Salmonella and antimicrobial resistance in an animal-based agriculture river system. Sci. Total Environ. 2014, 472, 654-661. [CrossRef] [PubMed]

23. Miranda, C.D.; Zemelman, R. Antimicrobial multiresistance in bacteria isolated from freshwater Chilean salmon farms. Sci. Total Environ. 2002, 293, 207-218. [CrossRef] 
24. Bengtsson-Palme, J.; Kristiansson, E.; Larsson, D.G.J. Environmental factors influencing the development and spread of antibiotic resistance. FEMS Microbiol. Rev. 2018, 42, 68-80. [CrossRef]

25. Singer, A.C.; Shaw, H.; Rhodes, V.; Hart, A. Review of antimicrobial resistance in the environment and its relevance to environmental regulators. Front. Microbiol. 2016, 7, 1-22. [CrossRef]

26. Redding, L.E.; Cubas-Delgado, F.; Sammel, M.D.; Smith, G.; Galligan, D.T.; Levy, M.Z.; Hennessy, S. Antibiotic residues in milk from small dairy farms in rural Peru. Food Addit. Contam. Part A Chem. Anal. Control Expo. Risk Assess. 2014, 31, 1001-1008. [CrossRef]

27. World Organisation for Animal Health One Health at a Glance. Available online: https://www.oie.int/en/for-the-media/ onehealth/ (accessed on 9 March 2021).

28. World Organisation for Animal Health International Partnership to Address Human-Animal-Environment Health Risks Gets a Boost. Available online: https://www.oie.int/en/for-the-media/press-releases/detail/article/international-partnership-toaddress-human-animal-environment-health-risks-gets-a-boost/ (accessed on 9 March 2021).

29. World Health Organization Global Framework for Development \& Stewardship to Combat Antimicrobial Resistance: Draft. Available online: https:/ / www.who.int/publications/m/item/global-framework-for-development-stewardship-to-combatantimicrobial-resistance-draft (accessed on 9 March 2021).

30. World Health Organization. WHO Report on Surveillance of Antibiotic Consumption 2016-2018 Early Implementation; World Health Organization: Geneva, Switzerland, 2018; ISBN 9789241514880.

31. Dirección General de Medicamentos Insumos y Drogas (DIGEMID). Plan Nacional Contra la Resistencia a los Antimicrobianos; DIGEMID: Lima, Peru, 2017.

32. Elías, R.; Berenguel, R.; Beraún, Y.; Enrique, C.; Vásquez, P. Gestión y vigilancia sanitaria de la fauna silvestre en el Perú. Salud Tecnol. Vet. 2020, 8, 19-26. [CrossRef]

33. Schneider, M.C.; Aguilera, X.P.; Smith, R.M.; Moynihan, M.J.; Da Silva, J.B.; Aldighieri, S.; Almiron, M. Importance of animal/human health interface in potential Public Health Emergencies of International Concern in the Americas. Rev. Panam. Salud Publica/Pan Am. J. Public Health 2011, 29, 371-379. [CrossRef]

34. Queenan, K.; Garnier, J.; Nielsen, L.R.; Buttigieg, S.; De Meneghi, D.; Holmberg, M.; Zinsstag, J.; Rüegg, S.; Häsler, B.; Kock, R. Roadmap to a one health agenda 2030. CAB Rev. 2017, 12, 17. [CrossRef]

35. Rosa, G.; Huaylinos, M.L.; Gil, A.; Lanata, C.; Clasen, T. Assessing the consistency and microbiological effectiveness of household water treatment practices by urban and rural populations claiming to treat their water at home: A case study in Peru. PLoS ONE 2014, 9, e114997. [CrossRef]

36. Hartinger, S.M.; Nuño, N.; Hattendorf, J.; Verastegui, H.; Karlen, W.; Ortiz, M.; Mäusezahl, D. A factorial cluster-randomised controlled trial combining home-environmental and early child development interventions to improve child health and development: Rationale, trial design and baseline findings. BMC Med Res. Methodol. 2020, 20, 1-12. [CrossRef] [PubMed]

37. OXFAM-DELAGUA. Oxfam-Delagua Portable Water Testing Kit-Users Manual-Version 4.3; OXFAM-DELAGUA: Wiltshire, UK, 2012; pp. 1-64.

38. MacFaddin, J.F. Biochemical Tests for Identification of Medical Bacteria, 3rd ed.; Lippincott Williams \& Wilkins: Philadelphia, PA, USA, 2000.

39. Clinical and Laboratory Standards Institute (CLSI) Performance Standards for Antimicrobial Susceptibility Testing. 30th ed. Available online: https:/ / clsi.org/standards/products/microbiology/documents/m100/ (accessed on 8 March 2021).

40. Autoridad Nacional del Agua Comparison of Four Phenotypic Methods to Detect Extended-Spectrum Betalactamases. Available online: https://www.ana.gob.pe/normatividad/resolucion-administrativa-no-656-2017-ana-aaa-xipaala-bap (accessed on 8 February 2021).

41. Belaaouaj, A.; Lapoumeroulie, C.; Caniça, M.M.; Vedel, G.; Névot, P.; Krishnamoorthy, R.; Paul, G. Nucleotide sequences of the genes coding for the TEM-like $\beta$-lactamases IRT-1 and IRT-2 (formerly called TRI-1 and TRI-2). FEMS Microbiol. Lett. 1994, 120, 75-80. [CrossRef]

42. Pitout, J.D.D.; Thomson, K.S.; Hanson, N.D.; Ehrhardt, A.F.; Moland, E.S.; Sanders, C.C. $\beta$-lactamases responsible for resistance to expanded-spectrum cephalosporins in Klebsiella pneumoniae, Escherichia coli, and Proteus mirabilis isolates recovered in South Africa. Antimicrob. Agents Chemother. 1998, 42, 1350-1354. [CrossRef]

43. Jouini, A.; Vinué, L.; Ben Slama, K.; Sáenz, Y.; Klibi, N.; Hammami, S.; Boudabous, A.; Torres, C. Characterization of CTX-M and SHV extended-spectrum $\beta$-lactamases and associated resistance genes in Escherichia coli strains of food samples in Tunisia. J. Antimicrob. Chemother. 2007, 60, 1137-1141. [CrossRef]

44. Batchelor, M.; Hopkins, K.; Threlfall, E.J.; Clifton-Hadley, F.A.; Stallwood, A.D.; Davies, R.H.; Liebana, E. blaCTX-M genes in clinical Salmonella isolates recovered from humans in England and Wales from 1992 to 2003. Antimicrob. Agents Chemother. 2005, 49, 1319-1322. [CrossRef]

45. World Health Organization. Antimicrobial Resistance. Available online: https://www.who.int/health-topics/antimicrobialresistance (accessed on 30 March 2021).

46. Magiorakos, A.P.; Srinivasan, A.; Carey, R.B.; Carmeli, Y.; Falagas, M.E.; Giske, C.G.; Harbarth, S.; Hindler, J.F.; Kahlmeter, G.; Olsson-Liljequist, B.; et al. Multidrug-resistant, extensively drug-resistant and pandrug-resistant bacteria: An international expert proposal for interim standard definitions for acquired resistance. Clin. Microbiol. Infect. 2012, 18, 268-281. [CrossRef] [PubMed]

47. Lebov, J.; Grieger, K.; Womack, D.; Zaccaro, D.; Whitehead, N.; Kowalcyk, B.; MacDonald, P.D.M. A framework for One Health research. One Health 2017, 3, 44-50. [CrossRef] 
48. World Health Organization. Guidelines for Drinking Water, 4th ed.; WHO: Geneva, Switzerland, 2017; ISBN 9789241549950.

49. Ministerio de Salud. Reglamento de la Calidad del Agua para Consumo Humano; Ministerio de Salud: Lima, Peru, $2011 ;$ pp. 1-46.

50. MVCS. DATASS: Modelo Para la Toma de Decisiones en Saneamiento Sistema de Diagnóstico Sobre Abastecimiento de Agua y Saneamiento en el Ámbito Rural; Ministerio de Vivienda, Construcción y Saneamiento: Lima, Peru, 2019.

51. Bartram, J.; Bos, R.; Dufour, A. (Eds.) Animal Waste, Water Quality and Human Health; World Health Organizations: London, UK, 2013; Volume 12, ISBN 9781780401232.

52. CARE-Perú. Diagnóstico de Saneamiento Integral de la Región Cajamarca; CARE-Peru: Lima, Peru, 2008.

53. Gil, A.I.; Lanata, C.F.; Hartinger, S.M.; Mäusezahl, D.; Padilla, B.; Ochoa, T.J.; Lozada, M.; Pineda, I.; Verastegui, H. Fecal contamination of food, water, hands, and kitchen utensils at the household level in rural areas of Peru. J. Environ. Health 2014, 76, 102-106.

54. WHO. Managing Water in the Home: Accelerated Health Gains from Improved Water Supply; World Health Organization: Geneva, Switzerland, 2002; Volume 8, pp. 1-83.

55. Granados-Chinchilla, F.; Rodríguez, C. Tetracyclines in Food and Feedingstuffs: From Regulation to Analytical Methods, Bacterial Resistance, and Environmental and Health Implications. J. Anal. Methods Chem. 2017, 2017. [CrossRef]

56. Gu, Y.; Shen, S.; Han, B.; Tian, X.; Yang, F.; Zhang, K. Family livestock waste: An ignored pollutant resource of antibiotic resistance genes. Ecotoxicol. Environ. Saf. 2020, 197, 110567. [CrossRef]

57. Wang, L.; Wang, J.; Wang, J.; Zhu, L.; Yang, L.; Yang, R. Distribution characteristics of antibiotic resistant bacteria and genes in fresh and composted manures of livestock farms. Sci. Total Environ. 2019, 695, 133781. [CrossRef]

58. Mishra, M.; Arukha, A.P.; Patel, A.K.; Behera, N.; Mohanta, T.K.; Yadav, D. Multi-drug resistant coliform: Water sanitary standards and health hazards. Front. Pharmacol. 2018, 9, 1-8. [CrossRef]

59. Agensi, A.; Tibyangye, J.; Tamale, A.; Agwu, E.; Amongi, C. Contamination Potentials of Household Water Handling and Storage Practices in Kirundo Subcounty, Kisoro District, Uganda. J. Environ. Public Health 2019, 2019, 1-8. [CrossRef]

60. Levy, K.; Nelson, K.L.; Hubbard, A.; Eisenberg, J.N.S. Following the water: A controlled study of drinking water storage in Northern Coastal Ecuador. Environ. Health Perspect. 2008, 116, 1533-1540. [CrossRef]

61. Ercumen, A.; Pickering, A.J.; Kwong, L.H.; Arnold, B.F.; Parvez, S.M.; Alam, M.; Sen, D.; Islam, S.; Kullmann, C.; Chase, C.; et al. Animal Feces Contribute to Domestic Fecal Contamination: Evidence from E. coli Measured in Water, Hands, Food, Flies, and Soil in Bangladesh. Environ. Sci. Technol. 2017, 51. [CrossRef]

62. Zambrano, L.D.; Levy, K.; Menezes, N.P.; Freeman, M.C. Human diarrhea infections associated with domestic animal husbandry: A systematic review and meta-analysis. Trans. R. Soc. Trop. Med. Hyg. 2014, 108, 313-325. [CrossRef] [PubMed]

63. Centers for Disease Control and Prevention Shigellosis-Chapter 4-2020 Yellow Book I Travelers' Health I CDC. Available online: https://wwwnc.cdc.gov/travel/yellowbook/2020/travel-related-infectious-diseases/shigellosis (accessed on 31 March 2021).

64. Ortega-Paredes, D.; Haro, M.; Leoro-Garzón, P.; Barba, P.; Loaiza, K.; Mora, F.; Fors, M.; Vinueza-Burgos, C.; Fernández-Moreira, E. Multidrug-resistant Escherichia coli isolated from canine faeces in a public park in Quito, Ecuador. J. Glob. Antimicrob. Resist. 2019, 18, 263-268. [CrossRef]

65. Ferrer, N.; Folch, A.; Masó, G.; Sanchez, S.; Sanchez-Vila, X. What are the main factors influencing the presence of faecal bacteria pollution in groundwater systems in developing countries? J. Contam. Hydrol. 2020, 228, 103556. [CrossRef] [PubMed] 